\title{
Antioxidant Enzymes Activity in the Elaeis guineensis Jacq. Submitted to Drought
}

\author{
Cândido O. Neto ${ }^{1}$, Maria E. Rocha ${ }^{1}$, Mayra T. Abade ${ }^{1}$, Glauco A. Nogueira ${ }^{1}$, Vitor R. Nascimento ${ }^{1}$, \\ Kerolem P. Cardoso ${ }^{1}$, Ana E. Brito ${ }^{1}$, Liliane C. Machado ${ }^{1}$, Jéssica T. Martins ${ }^{1}$, \\ Thays C. Costa $^{1} \&$ Ricardo S. Okumura ${ }^{1}$ \\ ${ }^{1}$ Institute of Agrarian Sciences, Universidade Federal Rural da Amazônia, Brazil \\ Correspondence: Glauco A. Nogueira, Institute of Agrarian Sciences, Universidade Federal Rural da Amazônia, \\ Avenida Presidente Tancredo Neves, No 2501 Bairro, Terra Firme, Cidade, Belém, Pará, Brazil. Tel: \\ 55-21-999-044-368. E-mail: glauand@yahoo.com.br
}

$\begin{array}{lc}\text { Received: April 6, 2018 } & \text { Accepted: June 2, 2018 } \quad \text { Online Published: July 15, } 2018 \\ \text { doi:10.5539/jas.v10n8p245 } & \text { URL: https://doi.org/10.5539/jas.v10n8p245 }\end{array}$

\begin{abstract}
Oil palm is a very responsive culture in relation to climate change that intensifies or lowers its productivity. Thus, the objective of this study is to evaluate the activity of antioxidant enzymes in two genotypes of $E$. guineensis, both under water deficiency. The experiment conducted in a greenhouse at UFRA used genotypes 2528 and 2501 of $E$. guineensis submitted to water deficiency from the $10^{\text {th }}$ day. The biochemical analysis was evaluated at the $5 \%$ level of significance by the Tukey test. The antioxidant variables analyzed were superoxide dismutase, catalase activity, ascorbate peroxidase activity, Malondialdeído (MDA), Glutathione and ascorbic acid content. In view of the obtained results, it was observed increases of the antioxidant enzymes when the genotypes were submitted to the water deficiency, presented significance for the results. Therefore, the study suggests that oil palm had a good use and adaptation when submitted to water deficit and that genotype 2528 was more responsive to maintain its vital biochemical activities.
\end{abstract}

Keyword: biochemistry, hydric stress, oxidative stress

\section{Introduction}

Drought is one of the environmental factors of greater agricultural importance, as it causes many physiological, metabolic and morphological alterations causing numerous deleterious effects on plant growth, water relations and photosynthesis (Hasanuzzaman et al., 2014). Concomitant to this, the oil palm responds negatively when subjected to drought affecting the productive processes of the species (Al-Amin et al., 2011).

The oil palm (Elaeis guineensis Jacq.) is an oleaginous plant belonging to the Arecaceae family and cultivated mainly in tropical regions such as Latin America, Southeast Asia and Africa (Luis et al., 2010). Because it is a cultivation of manual and long cycle cultivation, it has great productive potential, standing out for the high productivity of oil, used in food, industrial and agro-energy processes (Zimmer, 2010).

Several studies indicate that under conditions of water deficiency the activity of photosynthesis is reduced, regardless of the type of metabolism (Cha-um et al., 2010; Cao et al., 2011; Son et al., 2011; Zlatev \& Lindon, 2012; Ashraf \& Harris, 2013). Thus, the reduction of palm oil production can be directly related to the inhibition of the photosynthetic rate, which is caused, among other factors, by the low relative water content (Fahramand et al., 2014; Zain et al., 2014).

As a consequence, decreases in $\mathrm{CO}_{2}$ fixation under stress conditions can cause photochemical and biochemical imbalances of photosynthesis (Asada \& Badger, 1984). Resulting in excessive production of reactive oxygen species (ROS) which are unstable molecules capable of causing enzymatic damage affecting proteins, carbohydrates, lipids and nucleic acids (Silva \& Gonçalves, 2010).

These molecules can be formed as a result of excitation, producing singlet oxygen $\left({ }^{1} \mathrm{O}_{2}\right)$ or reducing $\mathrm{O}_{2}$ to the anionic superoxide radical $\left(\mathrm{O}_{2}{ }^{-}\right)$, hidroperoxylic radical $\left(\mathrm{HO}_{2}{ }^{\circ}\right)$, hydrogen peroxide $\left(\mathrm{H}_{2} \mathrm{O}_{2}\right)$ and hydroxyl radical $\left(\mathrm{OH}^{*}\right)$ (Bhattacharjee, 2010). Despite the importance of $\mathrm{O}_{2}$ for the performance of cellular functions, under stress conditions there is ROS formation in metabolic events (Karuppanapandian et al., 2011). 
However, plants have a complex antioxidant system to contain the deleterious effects of reactive oxygen species, in which specific enzymes act to neutralize the action of these radicals (Miller et al., 2010), among the antioxidant enzymes superoxide dismutase (SOD), ascorbato peroxidase (APX), catalase (CAT) among others, and among the main antioxidant metabolites are ascorbic acid (AsA) and the glutathione (GSH) (Kim \& Kwak, 2010).

Therefore, due to the great importance of the oil palm it is necessary to understand its physiological or biochemical functions when submitted to regions with water restriction. Thus, the objective of this study is to evaluate the activity of antioxidant enzymes in two genotypes of E. guineensis, both under water deficiency.

\section{Material and Methods}

\subsection{Plant Material and Treatment}

Young plants of E. guineensis with 10 months from Embrapa Amazônia Oriental with similar aspects and sizes were selected and placed in $20 \mathrm{~L}$ pots filled with soil and bovine manure $(3: 1 \mathrm{v} / \mathrm{v})$ substrate. The experiment was carried out in a greenhouse at the Federal Rural University of Amazônia, Capitão Poço campus (Latitude $1^{\circ} 44^{\prime} 47^{\prime \prime} \mathrm{S}$ and Longitude $47^{\circ} 3^{\prime} 34^{\prime \prime} \mathrm{W}$ ), Brazil, and biochemical analyzes in laboratory biodiversity studies of higher plants.

The plants were submitted to two water regimes: irrigated (control) and water deficit (total irrigation suspension at the beginning of the experiment), in a period of 30 days. During the experimental period the plants called control were irrigated daily to replace the lost water, in which the volume of water applied was due to the size of the vessel used.

\subsection{Biochemical Analyses of the Samples}

The relative water content (RWC) was determined according to Slavick (1974). The activity of superoxide dismutase (SOD) was determined according to Giannopolitis and Ries (1977). Aliquots of $0.1 \mathrm{~mL}$ of the protein extract were transferred to test tubes containing reaction medium composed of potassium phosphate buffer 100 $\mathrm{mM}$ (TFK; pH 7.8); $0.1 \mathrm{mM}$ of EDTA; 0.1\% (v/v) of 2-Mercaptoetanol; $0.1 \%(\mathrm{v} / \mathrm{v})$ of Triton X-100; $30 \mathrm{mg}$ of Polivinilpirrolidona (PVP); and, $20 \mathrm{mM}$ from ascorbate. The reaction was initiated by addition of $13 \mathrm{mM}$ of methionine ( $\mathrm{pH} 7.8$ ); $2 \mu \mathrm{M}$ of riboflavin; $0.075 \mathrm{mM}$ of nitrotetrazolium blue (NBT). After $5 \mathrm{~min}$, the readings were performed at $560 \mathrm{~nm}$ and the activity of SOD expressed in (enzymatic unit) $\mathrm{U} \mathrm{mg}^{-1}$ protein.

\subsubsection{Extraction: For Leaves and Roots}

The extract for the determination of the activity of the SOD, APX and CAT enzymes was obtained from the homogenization in mortar at $4{ }^{\circ} \mathrm{C}$ of $0.1 \mathrm{~g}$ of lyophilized leaf powder and root with $5 \mathrm{ml}$ of potassium phosphate buffer solution (at $4{ }^{\circ} \mathrm{C}$ ) at $0.1 \mathrm{mM}, \mathrm{pH} 7.0$, containing $0.1 \mathrm{mM}$ EDTA, followed by homogenization for 4 min. The additions of the phosphate buffer were made in a fragmented form, $50 \%$ of the total volume of this solution $(2.5 \mathrm{ml}$ ) being used in the homogenization for $2 \mathrm{~min}$, after which the other $50 \%$ were immediately added, the mixture being homogenized in time equivalent to the previous one. The homogenate was filtered on nylon tissue and transferred to test tubes, and held at $4{ }^{\circ} \mathrm{C}$ for two hours, with occasional shaking. The filtered homogenate was centrifuged at $12,000 \times \mathrm{g}$ for $15 \mathrm{~min}$ at $4{ }^{\circ} \mathrm{C}$. The supernatant, the crude extract, was stored in a freezer at $-80{ }^{\circ} \mathrm{C}$ until used in enzyme activity assays.

\subsubsection{Determination of the Concentration of Malonic Aldehyde (MDA)}

Determination of the concentration of malonic aldehyde (TCA) $(0.1 \% \mathrm{p} / \mathrm{v})$. The homogenate was centrifuged at $10,000 \times \mathrm{g}$ for $15 \mathrm{~min}$ at $4{ }^{\circ} \mathrm{C}$ and the supernatant was collected and used in the determination of the concentrations of MDA.

\subsubsection{Extraction of GSH From Crude Yeast Extracts by ATPS}

A total volume of $1 \mathrm{~mL}$ crude yeast extracts containing $0.22 \mathrm{~g} / \mathrm{L}$ glutathione was added into aqueous two-phase systems, and the final concentration of GSH in ATPS was $20 \mathrm{mg} / \mathrm{L}$. The systems containing different salts were prepared by directly dissolving the salt powder into the system. The systems were mixed thoroughly and centrifuged at 3,000 rpm for $30 \mathrm{~min}$ to assist phase separation. The centrifuged systems were then allowed to settle for $5 \mathrm{~min}$ to separate into two clear phases. Samples from top and bottom phases were then carefully removed and assayed for glutathione concentration (Wu et al., 2004).

For the determination of catalase activity (CAT) the methodology was used according to Havir and Mchale (1987), which the consumption of $\mathrm{H}_{2} \mathrm{O}_{2}$ was based on the decrease of the absorbance at $240 \mathrm{~nm} .20 \mu \mathrm{L}$ aliquots of the extract were added to $3 \mathrm{~mL}$ of reaction medium consisting of $50 \mathrm{mM}$ potassium phosphate buffer ( $\mathrm{pH} 7.0$ ) at $30{ }^{\circ} \mathrm{C}$, plus $12.5 \mathrm{mM} \mathrm{H}_{2} \mathrm{O}_{2}$. The CAT activity was expressed in $\mathrm{nmol} \mathrm{H}_{2} \mathrm{O}_{2} \mathrm{~g}^{-1} \mathrm{DM} \mathrm{min}{ }^{-1}$. 
To measure the activity of ascorbate peroxidase (APX), the consumption of ascorbate was detected by decreasing the absorbance at $290 \mathrm{~nm}$, according to Nakano and Asada (1981). $0.1 \mathrm{~mL}$ aliquots of the extract were transferred to test tubes containing $2.7 \mathrm{~mL}$ of $50 \mathrm{mM}$ potassium phosphate buffer ( $\mathrm{pH} 6.0$ ) and $0.8 \mathrm{mM}$ L-ascorbate. The reaction was started by the addition of $2 \mathrm{mM} \mathrm{H}_{2} \mathrm{O}_{2}$ and the enzymatic activity was expressed in $\mu \mathrm{mol}$ ascorbate $\mathrm{g}^{-1} \mathrm{DM} \mathrm{min}^{-1}$.

The MDA was determined from $0.3 \mathrm{~g}$ of fresh Plant tissue mass in $4.0 \mathrm{~mL}$ of Trichloroacetic Acid (TCA $0.1 \%$ $\mathrm{w} / \mathrm{v}$ ), $500 \mu \mathrm{L}$ of the extract was diluted in $1.5 \mathrm{~mL}$ of the solution of Tiobarbituric acid (TBA $0.5 \%$ made in TCA 20\%). Samples were read at $532 \mathrm{~nm}$ according to the methodology of Cakmak and Horst (1991), expressing the results in nmol g-1 FM.

Glutathione (GSH) was determined by mixing $200 \mu \mathrm{L}$ of supernatant and $1800 \mu \mathrm{L}$ of reaction mix containing 100 $\mu \mathrm{L}$ phosphate buffer ( $\mathrm{pH} 7.6$ ) and $0.60 \mathrm{mM}$ 2-nitrobenzoic acid, the absorbance being measured at $412 \mathrm{~nm}$, with unit expressed in $\mu \mathrm{mol} \mathrm{g}{ }^{-1} \mathrm{FW}$ (Wu et al., 2006). The ascorbic acid content (AsA) was performed according to Arakawa et al. (1981), for which one gram of homogenized fresh tissue was used in $5 \mathrm{ml}$ of $5 \%$ (w/v) TCA in an ice bath. After reading at $534 \mathrm{~nm}$. The AsA content was determined using a standard curve with $\mu \mathrm{mol} \mathrm{g}^{-1} \mathrm{FW}$ unit.

\subsection{Statistical Design and Data Analysis}

The experiment was carried out in a completely randomized design with $2 \times 2$ factorial treatments [two water conditions (control and drought) $\times$ two genotypes (2501 and 2528)], with five replications per treatment. The results of the analyzes were submitted to Shapiro-Wilks (Shapiro \& Wilks, 1965) and Levene (Box, 1953) tests for normality and homoscedasticity, respectively. Once the assumptions for analysis of variance were met, the data were submitted to statistical evaluations.

In order to evaluate the comparative effect of water deficiency among the genotypes, the analysis of variance (ANAVA) and the mean values compared by the Tukey test at $5 \%$ of probability using the statistical program SISVAR 5.3 and the graphs reproduced by the software Microsoft Excel 2010.

\section{Results}

\subsection{Relative Water Content}

With drought stress being prolonged, the relative water content (RWC) decreased significantly, comparing to the control treatment in the oil palm genotypes, which presented reduction of $19 \%$ for 2528 and $22 \%$ for the 2501 . However, there was no significant difference between the two genotypes (Figure 1).

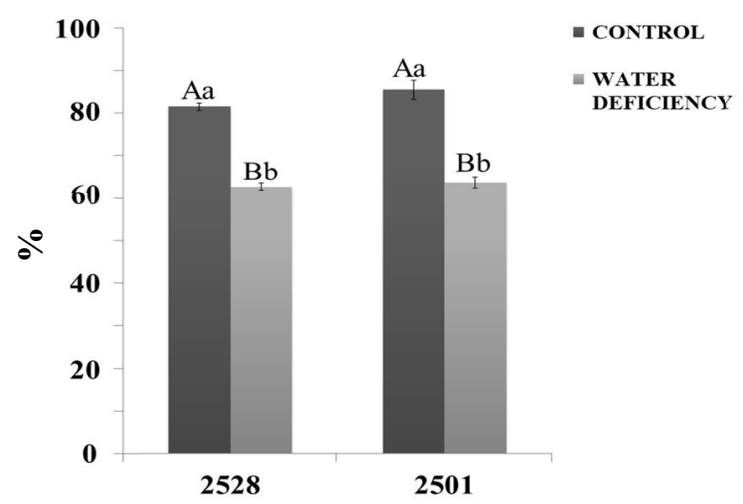

Figure 1. Relative water content in leaves of palm genotypes under drought

Note. Different letters indicate a significant difference by the Tukey test $(p<0.01)$. The bars represent the standard error of the mean.

\subsection{Activity of Antioxidant Enzymes}

The activity of the antioxidant enzymes increased significantly when the genotypes were submitted to water restriction, for both leaves and roots of the oil palm. The results of this study showed that the activity of SOD showed increased of $74 \%$ and $77 \%$ to 2528 and, $72 \%$ and $75 \%$ to 2501 (Figures $2 \mathrm{~A}$ and 2E), there was no significant difference between the genotypes. 
CAT increased $46 \%$ and $43 \%$ to 2528 and $44 \%$ and $41 \%$ to 2501 (Figures $2 \mathrm{~B}$ and $2 \mathrm{~F}$ ), with a significant difference between the genotypes; it was observed that APX increased its activity in $33 \%$ and $28 \%$ to 2528 and $30 \%$ and $26 \%$ to 2501 (Figures $2 \mathrm{C}$ and $2 \mathrm{G}$ ), there was a significant difference only for leaf in the condition of control treatment; and MDA showed increase of $18 \%$ and $29 \%$ to 2528 and, $15 \%$ and $20 \%$ to 2501 (Figures $2 \mathrm{D}$ and $2 \mathrm{H}$ ), there was no significant difference between the genotypes for root under control treatment.
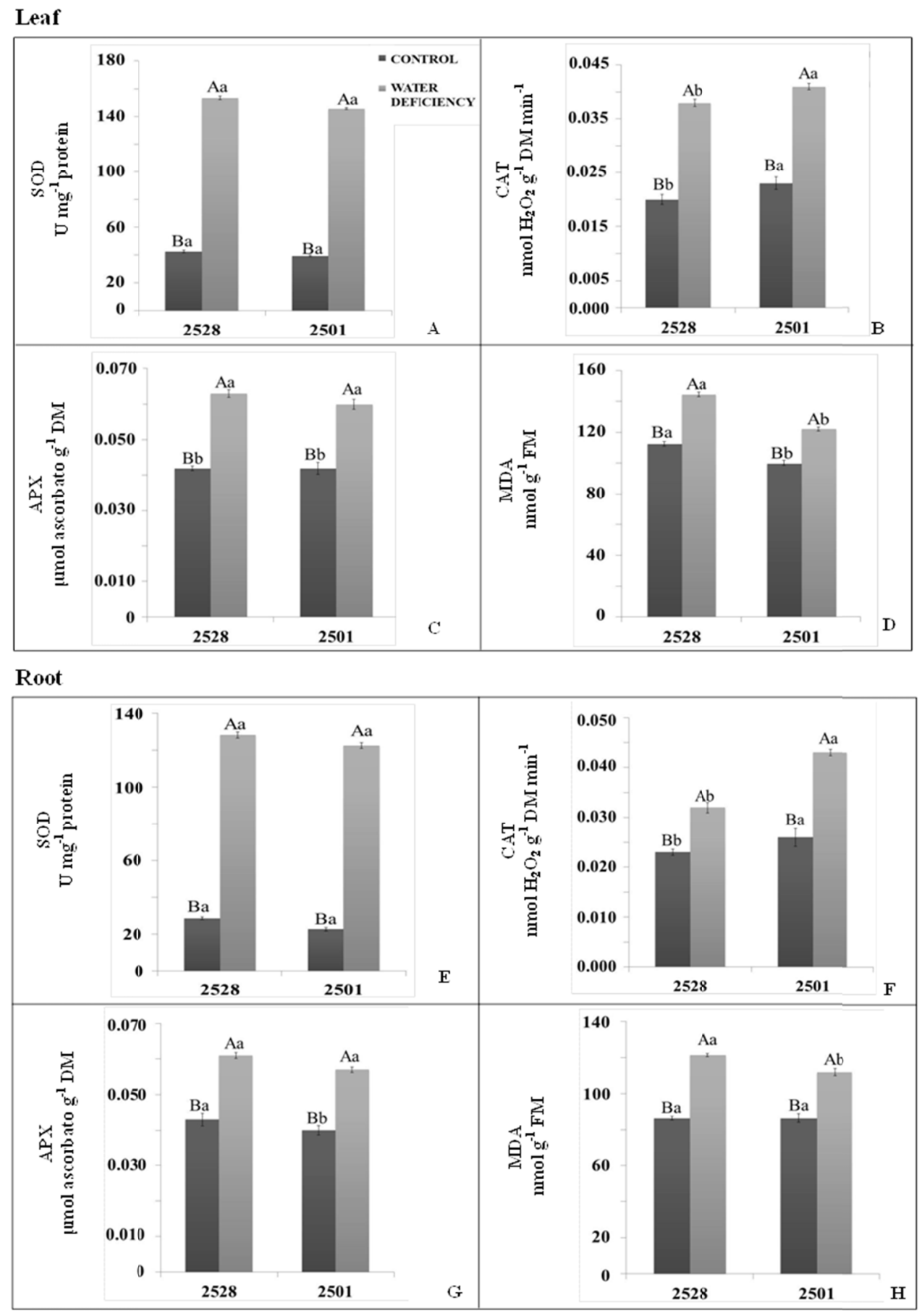

Figure 2. Activity of SOD (A, E), CAT (B, F), APX (C, G) and MDA (D, H) in leaves and roots of oil palm genotypes under drought

Note. Different letters indicate a significant difference by the Tukey test $(p<0.05)$. The bars represent the standard error of the mean. 


\subsection{Content of GSH and AsA}

In comparison to control, the drought stress increased the contents of GSH and AsA in leaves and roots of both genotypes, showing a significant increase in glutathione in $53 \%$ and $36 \%$ for 2528 and $61 \%$ and $52 \%$ for 2501 (Figures $3 \mathrm{~A}$ and $3 \mathrm{~B}$ ). There was no significant difference between genotypes only for leaves of the plants under control and for ascorbic acid 51\% and 55\% for 2528 and $27 \%$ and 25 for 2501 (Figures 3C and 3D), with genotype 2528 being highlighted in the roots.

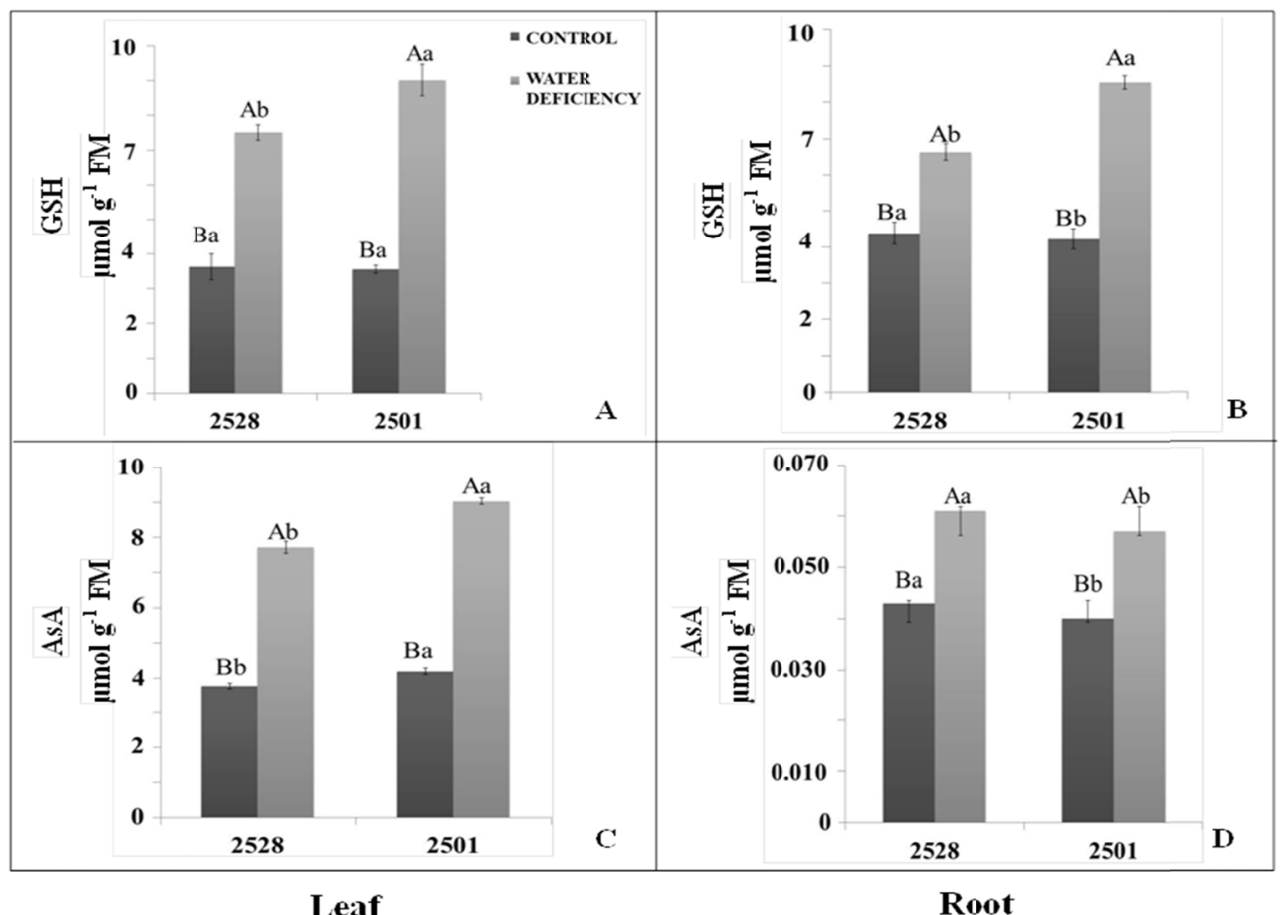

Figure 3. Effect of drought under concentrations of GSH (A, B) and AsA (C, D) in leaves and roots of oil palm genotypes

Note. Different letters indicate a significant difference by the Tukey test $(p<0.05)$. The bars represent the standard error of the mean.

\section{Discusion}

\subsection{Relative Water Content}

The reason for the reduction of the RWC can be explained by the stomatal closure due to the maintenance of the plant in the water suspension period as a strategic form in response to the signaling triggered by abscisic acid (Hong-Bo et al., 2008). Water deficiency the two genotypes lose more water than when under control treatment but possibly maintains their water status due to the plant's ability to survive severe water deficits by restricting loss through the leaf epidermis after the stoma has reached a minimum opening (El-Jaafari et al., 2000).

\subsection{Activity of Antioxidant Enzymes}

The significant increase of the antioxidant enzymes in oil palm under water deficiency probably occurred due to the development of these mechanisms in the plant to prevent and/or neutralize the oxidative stress caused by reactive oxygen species (ROS) (Pintó-Marijuan \& Munné-Bosch, 2014).

When plants undergo stress, they develop defense mechanisms that involve non-enzymatic water-soluble antioxidant compounds (glutathione), which provide electrons and act in conjunction with antioxidant enzymes (SOD, APX and CAT), which catalyze redox reactions (Kruk et al., 2014; Miret \& Munné-Bosch, 2015). Concomitant to this, the protection resulting from the enzymatic activities may have important influence under the tolerance of the species submitted to drought.

Nevertheless, it was possible to observe that the activity of SOD, known to confer tolerance to oxidative stress and that acts as the first line of defense against ROS, possibly diminished the damage caused in the oil palm 
genotypes as a response to metabolize the radicals produced superoxides (Jaleel et al., 2007). SOD, which may be mitochondrial, cytosolic or chloroplastidic, is responsible for the dismutation of $\mathrm{O}_{2}$ converting it to hydrogen peroxide and oxygen (Grob et al., 2013).

Ascorbate peroxidase and catalase (CAT), which are enzymes that will detoxify the $\mathrm{H}_{2} \mathrm{O}_{2}$ compounds generated by oxidative stress in order to generate other products that are not toxic to the plant cell (Bhattacharjee, 2010) are required. That is, the combined actions of SOD and CAT are crucial to mitigate the effects of oxidative stress, since the first involves the dismutation of $\mathrm{O}_{2}$ in $\mathrm{H}_{2} \mathrm{O}_{2}$ and the latter decomposes $\mathrm{H}_{2} \mathrm{O}_{2}$ in water and $\mathrm{O}_{2}$, and may indicate an important role in the control of accumulation of $\mathrm{H}_{2} \mathrm{O}_{2}$ from oil palm subjected to water deficiency.

The APX enzyme may also have been directly involved in the detoxification components of $\mathrm{H}_{2} \mathrm{O}_{2}$, due to the stressful condition (Bhatt \& Tripathi, 2011). Thus, it is possible to observe that the increase of the enzymatic activities, during the studied period, shows the defense of the plant in the destruction of free radicals as a form of prevention to more severe damages.

With the permanence of the water suspension, there was possibly loss of cell compartmentalization in the two oil palm genotypes, which is accompanied by the increase in the lipid peroxidation caused by ROS formation, being this peroxidation estimated by the concentration of MDA, that is, the accumulation of MDA in a tissue is widely used to estimate cell damage (Sung \& Jeng, 1994).

Thus, it is possible to observe that the concentrations of MDA increased significantly when the genotypes were under treatment with water suspension, inferring the increase of the lipid peroxidation. However, with the action of the antioxidant enzymes it was observed a reduction of the oxidative damages in the tissues of the genotypes under water deficiency.

\subsection{Content of Glutathione and Ascorbic Acid}

The importance of glutathione (GSH) has been studied because it is a tripeptide that is central to the cellular redox state in plants (Noctor et al., 2011). Due to the fundamental role in plant cells including redox signaling and homeostasis, we observed high concentrations of this component in leaves and roots of oil palm when submitted to water deficiency (Koprivova et al., 2010).

Therefore, it is possible that glutathione has acted in favor of the reduction of ROS acting as another plant defense system and being proportional to ascorbic acid (AsA) levels. From this, it is noted that some studies indicate that these two components act together in the ascorbate-glutathione cycle (ASC-GSH), doing the recycling of oxygenated compounds, showing increasing values for both roots and leaves in the two genotypes (Noctor \& Foyer, 1998; Serkedjieva, 2011).

\section{Conclusion}

The study suggests that oil palm had a good use and adaptation when submitted to water deficit and that genotype 2528 was more responsive to maintain its vital biochemical activities.

\section{References}

Akcay, U. C., Ercan, O., Kavas, M., Yildiz, L., Yilmaz, C., Oktem, H. A., \& Yucel, M. (2010). Drought-induced oxidative damage and antioxidant responses in peanut (Arachis hypogaea L.) seedlings. Plant Growth Regulation, 61(01), 21-28. https://doi.org/10.1007/s10725-010-9445-1

Al-Amin, A. Q., Filho, W. L., Maria, D. L. T. J., Jaafar, A. H., \& Ghani, Z. A. (2011). Assessing the impacts of climate change in the Malaysian agriculture sector and its influences in investment decision. Middle East J. Sci. Res., 7, 225-234. Retrieved from https://www.idosi.org/mejsr/mejsr7(2)11/17.pdf

Arakawa, N., Tsutsumi, K., Sanceda, N. G., Kurata, T., \& Inagaki, C. (1981). A rapid and sensitive method for the determination of ascorbic acid using 4, 7-diphenyl-1,10-phenanthroline. Agric. Biol. Chem., 45, 1289-1290. https://doi.org/10.1080/00021369.1981.10864697

Asada, K., \& Badger, M. R. (1984). Photoreduction of ${ }^{18} \mathrm{O}_{2}$ and $\mathrm{H}_{2}{ }^{18} \mathrm{O}_{2}$ with concomitante evolution of ${ }^{16} \mathrm{O}_{2}$ in intact spinach chloroplasts: Evidence for scavenging of hydrogen peroxide by peroxidase. Plant Cell Physiol., 25(7), 1169-1179. https://doi.org/10.1093/oxfordjournals.pcp.a076824

Ashraf, M., \& Harris, P. (2013). Photosynthesis under stressful environments: An overview. Photosynthetica, 51, 163-190. https://doi.org/10.1007/s11099-013-0021-6

Bhatt, I., \& Tripathi, B. N. (2011). Plant peroxiredoxins: Catalytic mechanisms, functional significance and future perspectives. Biotechnology Advances, 29, 850-859, https://doi.org/10.1016/j.biotechadv.2011.07.002 
Bhattacharjee, S. (2010). Sites of generation and physicochemical basis of formation of reactive oxygen species in plant cell. In S. D. Gupta (Ed.), Reactive oxygen species and antioxidants in higher plants (pp. 1-30). Enfield: Science Publishers. https://doi.org/10.1201/9781439854082-2

Box, G. E. P. (1953). Non-normality and tests on variances. Biometrika, 40, 318-335. https://doi.org/10.1093/ biomet/40.3-4.318

Cakmak, I., \& Horst, J. H. (1991). Effects of Aluminium on Lipid Peroxidation, Superoxide Dismutase, Catalase, and Peroxidase Activities in Root Tips of Soybean (Glycine Max). Physiologia Plantarum, 83, 463-468. https://doi.org/10.1111/j.1399-3054.1991.tb00121.x

Cao, H. X., Sun, C. X., Shao, H. B., \& Lei, X. T. (2011). Effect of low temperature and drought on the physiological and growth changes in oil palm seedlings. Afr. J. Biotechnol., 10, 2630-2637, https://doi.org/10.5897/AJB10.1272

Cha-um, S., Takabe, T., \& Kirdmanee, C. (2010). Osmotic potential, photosynthetic abilities and growth characters of oil palm (Elaeis guineensis Jacq.) seedlings in responses to polyethylene glycol-induced water deficit. Afr. J. Biotechnol., 9, 6509-6516. https://doi.org/10.5897/AJB10.809

El-Jaafari, S., Royo, C., Nachit, M. M., Fonzo, N. D., \& Araus, J. L. (2000). Durum wheat breeding for abiotic stresses resistance: Defining physiological traits and criteria. Options Mediterranéennes, Series A, 40, 251-256.

Fahramand, M., Mahmoody, M., Keykha, A., Noori, M., \& Rigi, K. (2014). Influence of abiotic stress on proline, photosynthetic enzymes and growth. Int. Res. J. Applied Basic Sci., 8, 257-265. Retrieved from http://www.irjabs.com/files_site/paperlist/r_2135_140515005216.pdf

Giannopolitis, C., \& Ries, S. (1977). Superoxide Dismutase. I. Occurrence in Higher Plants. Plant Physiology, 59, 309-314. https://doi.org/10.1104/pp.59.2.309

Grob, F., Durner, J., \& Gaupels, F. (2013). Nitricoxide, antioxidants and prooxidants in plant defence responses. Frontiers in Plant Science, 4(1), 419. https://doi.org/10.3389/fpls.2013.00419

Hasanuzzaman, M., Nahar, K., Gill, S. S., \& Fujita, M. (2014). Drought stress responses in plants, oxidative stress, and antioxidant defense. Climate Change and Plant Abiotic Stress Tolerance (pp. 209-250). Wiley-VCH Verlag GmbH \& Co. KGaA. https://doi.org/10.1002/9783527675265.ch09

Havir, E. A., \& McHale, N. A. (1987). Biochemical and Developmental Characterization of Multiple Forms of Catalase in Tobacco Leaves. Plant Physiology, 84, 450-455. https://doi.org/10.1104/pp.84.2.450

Hong-Bo, S., Li-Ye, C., \& Ming-An, S. (2008). Calcium as a versatile plant signal transducer under soil water stress. BioEssays, 30, 634-641. https://doi.org/10.1002/bies.20770

Jaleel, C. A., Manivannan, P., Sankar, B., Kishorekumar, A., Gopi, R., Somasundarum, R., \& Panneerselvan, R. (2007). Water deficit stress mitigation by calcium chloride in Catharanthus roseus: Effects on oxidative stress, praline metabolism and indole alkaloid accumulation. Colloids and Surfaces B: Bio interfaces, 60, 110-116. https://doi.org/10.1016/j.colsurfb.2007.06.006

Kim, Y. H., \& Kwak, S. S. (2010). The role of antioxidant enzymes during leaf development. In S. D. Gupta (Ed.), Reactive oxygen species and antioxidants in higher plants (pp. 129-150). Enfield: Science Publishers. https://doi.org/10.1201/9781439854082-8

Kruk, M. E., Kujawski, S., Mbaruku, G., Ramsey, K., Moyo, W., \& Freedman L. P. (2014). Disrespectful and abusive treatment during facility delivery in Tanzania: A facility and community survey. Health Policy and Planning, 33(1), e26-e33. https://doi.org/10.1093/heapol/czu079

Luis, Z. G., Bezerra, K. M. G., \& Scherwinski-Pereira, J. E. (2010). Adaptability and leaf anatomical features in oil palm seedlings produced by embryo rescue and pre-germinated seeds. Braz. J. Plant Physiology, 22, 209-215. https://doi.org/10.1590/S1677-04202010000300008

Messchmidt, A. A., Valmor, J. B., Zanandrea, I., Martinazzo, E. G., Radmann, E. B., \& Bacarin, M. A. (2015). Trocas gasosas e atividade antioxidante de portaenxertos de Prunus spp. submetidos ao estresse hídrico e alagamento. Rev. Fac. Agron., 114, 71-81.

Miller, G., Suzuki, N., Ciftci-yilmaz, S., \& Mittler, R. (2010). Reactive oxygen species homeostasis and signalling during drought and salinity stresses. Plant, Cell and Environment, 33, 453-467. https://doi.org/ 10.1111/j.1365-3040.2009.02041.x 
Miret, J. A., \& Munné-Bosch, S. (2015). Redox signaling and stress tolerance in plants: a focus on vitamin E. Ann. N.Y. Acad. Sci., 1340, 29-38. https://doi.org/10.1111/nyas.12639

Nakano, Y., \& Asada, K. (1981). Hydrogen-peroxide is scavenged by ascorbate-specifi c peroxidase in spinach-chloroplasts. Plant Cell Physiology, 22, 867-880. https://doi.org/10.1093/oxfordjournals.pcp. a076232

Noctor, G., \& Foyer, C. H. (1998). Ascorbate and glutathione: Keeping active oxygen under control. Annual Review of Plant Physiology and Plant Molecular Biology, 49, 249-279. https://doi.org/10.1146/annurev. arplant.49.1.249

Pintó-Marijuan, M., \& Munné-Bosh, S. (2014). Photo-oxidative stress markers as a measure of abiotic stress-induced leaf senescence: Advantages and limitations. Journal of Experimental Botany, 65, 3845-3857. https://doi.org/10.1093/jxb/eru086

Serkedjieva, J. (2011). Antioxidant effects of plant polyphenols: A case study of a polyphenol-rich extract from Geranium sanguineum L. In S. D. Gupta (Ed.), Reactive oxygen species and antioxidants in higher plants (Chap. 13, pp. 275-293). Enfield: Science Publishers.

Shapiro, S. S., \& Wilk, M. B. (1965). Analysis of variance test for normality (complete samples). Biometrika, 52, 591-411. https://doi.org/10.2307/2333709

Shvaleva, A. L., Silva, F. C., Breia, E., Jouve, L., Hausman, J. F., Almeida, M. H., ... Chaves, M. M. (2005). Metabolic reponses to water déficit in two Eucalyptus globulus clones with contrasting drought sensitivity. Tree Physiology, 26, 239-248. https://doi.org/10.1093/treephys/26.2.239

Silva, A. A., \& Gonçalves, R. C. (2010). Espécies reativas do oxigênio e as doenças respiratórias em grandes animais. Ciência Rural, 40, 994-1002. https://doi.org/10.1590/S0103-84782010005000037

Slavick, B. (1974). Methods of studying plant water relations (p. 449). New York: Springer Verlag.

Son, M. S., Song, J. Y., Lim, M. Y., Sivanesan, I., \& Jeong, B. R. (2011). Effect of silicon on tolerance to high temperatures and drought stress in euphorbia pulcherrima willd. Proceedings of the 5th International Conference on Silicon in Agriculture (pp. 1-188). September 13-18, 2011, Beijing, China.

Sung, J. M., \& Jeng, T. L. (1994). Lipid peroxidation and peroxide-scavenging enzymes associated with accelerated aging of peanut seed. Physiologia Plantarum, 91, 51-55, https://doi.org/10.1111/j.1399-3054. 1994.tb00658.x

Thirupathi, K., Jun-Cheol, M., Changsoo, K., Kumariah, M., \& Wook, K. (2011). Reactive oxygen species in plants: Their generation, signal transduction, andscavenging mechanisms. Australian Journal of Crop Science, 5, 709-725. Retrieved from http://www.cropj.com/kim_5_6_2011_709_725.pdf

Wu, G., Fang, Y. Z., Yang, S., Lupton, J. R., \& Turner, N. D. (2004). Glutathione metabolism and its implications for health. Nutr., 134(3), 489-492. https://doi.org/10.1093/jn/134.3.489

Wu, Q. S., Xia, R. X., \& Zou, Y. N. (2006). Reactive oxygen metabolism in mycorrhizal and non-mycorrhizal citrus (Poncirus trifoliata) seedlings subjected to water stress. Journal of Plant Physiology, 163, 1101-1110. https://doi.org/10.1016/j.jplph.2005.09.001

Zain, N. A., Ismail, M. R., Mahmood, M., Puteh, A., \& Ibrahim, M. H. (2014). Alleviation of water stress effects on MR220 rice by application of periodical water stress and potassium fertilization. Molecules, 19, 1795-1819. https://doi.org/10.3390/molecules19021795

Zimmer, Y. (2010). Competitiveness of rapeseed, soybeans and palm oil. Journal of Oilseed Brassica, 1, 84-90.

Zlatev, Z., \& Lindon, F. C. (2012). An overview on drought induced changes in plant growth, water relations and photosynthesis. Emir. J. Food Agric., 24, 57-72. https://doi.org/10.9755/ejfa.v24i1.10599

\section{Copyrights}

Copyright for this article is retained by the author (s), with first publication rights granted to the journal.

This is an open-access article distributed under the terms and conditions of the Creative Commons Attribution license (http://creativecommons.org/licenses/by/4.0/). 